\title{
Echt gebeurd? Verhalen of feiten? Over historische en literaire bijbelkritiek en de zeggenschap van de bijbel
}

H M Vroom
(Vrije Universiteit Amsterdam)

\section{ABSTRACT}

\section{Did it really happen? Facts or fiction? On historical and literary criticism of the Bible and the authority of Scripture}

A serious objection against Christian faith is that the Bible is not trustworthy because the history it relates does not correspond to the facts of history. In theology this problem is "solved" by some biblical scholars by an acceptance of the research methods that are used for all literature alike while others accept the historical critique by understanding the biblical history as a faithful but a-historical revelation. Fundamentalists reject the historical-critical objections and stress the inerrancy of Scripture. In this contribution these three "answers" are rejected: biblical studies shall take the (real) facts serious indeed (pace inerrancy), nor jump into an a-historical revelatory history next to historical criticism (pace strong Barthian views in the "Amsterdam School"), but neither read religious scriptures all in the same way "as all literature" — but apply academic methods as is appropriate for the Hebrew and Greek Bible.

\section{INLEIDING}

Is het allemaal wel echt gebeurd zoals het in de bijbel staat? De suggestie, wijd verbreid in onze cultuur, is dat de verhalen van religieuze tradities niet waar gebeurd zijn, en dat dit vooral christenen en moslims treft, omdat hindoes en boeddhisten veel minder van de waarheid van de verhalen afhankelijk zijn. Als iemand gelooft dat de uiteindelijke waarheid onuitspreekbaar is, dan heeft zo iemand er natuurlijk minder last van dat de verhalen over Arjuna en Krishna niet letterlijk gebeurd zijn. De Bhagavadgita vertelt ons waarheden over de verbanden waarin het leven staat, over onthechting en plicht: de strijd van de neven om het koninkrijk is secundair. Bij de Boeddha luistert het ook minder nauw. Voor de betekenis van de verhalen over zijn 'bekeringservaring' die hem

1 Navorsingsgenoot, Prof C J Wethmar, Departement Dogmatiek en Christelike Etiek, Universiteit van Pretoria. 
ertoe deed besluiten het paleis te verlaten en zich in een zwervend bestaan los te willen maken van valse voorstellingen over het leven, maakt het niet zoveel uit of het precies zo gegaan is. Als het een gecomponeerd verhaal zou zijn waarin wat Prins Gautama overkwam op een gestileerde manier is weergegeven, dan verandert er aan de betekenis niet zo heel veel. Dat geldt ook van de beroemde prediking van de Boeddha nadat hem via de gematigde weg van onthechting en meditatie de verlichting was overkomen. Wie zou eigenlijk verwachten dat die preek net zo gehouden is als die in de oude overleveringen is opgeschreven? Is de derde keer dat men een preek die "echt ergens over gaat" houdt, ooit woordelijk hetzelfde als de eerste keer? Of is die preek dan nog meer "to the point," omdat die op een bepaald punt wordt uitgediept en op een ander punt een uitweiding is weggelaten? Voor een religie waarin de historiciteit minder belangrijk is, maakt historische nauwkeurigheid minder uit.

Voor jodendom, islam en christendom ligt dit anders. Orthodox jodendom houdt zich strikt aan leefregels uit de Thora, omdat God op Sinaï met Israël een Verbond heeft gesloten. Het volk heeft verplichtingen op zich genomen en strakke regels aanvaard om zo in de nabijheid Gods te leven en een teken van de Schepper van hemel en aarde te zijn. Stel dat er geen historische gebeurtenis aan de verbondsluiting ten grondslag ligt, hoe redelijk is dan het geloof in het Verbond en de wil zich aan die leefregels te houden? Bovendien loopt er een lijn van het Verbond naar het land Israël-Palestina. Met welke redelijkheid beroepen sommige joden zich op Gods belofte dat Israël in dat land mag wonen? Ik zou van hieruit de geschillen tussen Joden en Palestijnen niet willen benaderen, maar we kunnen er ook niet aan voorbij dat godsdienstige aanspraken op het land Israël gebaseerd zijn of lijken te zijn op historische gebeurtenissen. Religieuze waarheidsaanspraken hebben in dit geval een stevige historische component. Als die zou wegvallen, hangen dan een aantal religieuze geloofsvoorstellingen niet in de lucht? Het christendom is minder afhankelijk van de historische "waarheid" van het verbond op de berg Sinaï, want het leidt niet tot aanspraken op het recht op een land. Toch speelt de verbondsgedachte een grote rol. Voor het christendom staat de historische waarheid over Jezus Christus centraal: het staat of valt met wat Jezus heeft gezegd en gedaan, hoe $\mathrm{Hij}$ is gestorven en of Hij is opgestaan. Als Jezus de Bergrede niet heeft uitgesproken, zou er dan iets aan de christelijke moraal veranderen? Als Jezus niet is opgestaan uit de doden, blijft 
het christendom dan hetzelfde of zijn we, zoals Paulus bijna uitroept, de armzaligsten van alle mensen?

Voor moslims ligt het weer anders. De islam erkent de Koran als de openbaring van God, in Arabische woorden gesproken tot de profeet Mohammed. Ook de tradities over wat de profeet verder heeft gezegd en hoe hij het gebod van God verder in zijn handelen heeft toegepast, heeft veel gezag. Over dat laatste bestaan talloze verhalen en een van de meest uitgebreide vakgebieden van de islamitische theologie is om na te sporen hoe oud verhalen zijn, van wie ze afkomstig zijn en hoe ze zijn overgeleverd. Dit is scherp en knap onderzoek, met grote kennis van de nuances van het Arabisch en enorm overzicht over de diverse tradities. Men stelt de tradities onder kritiek; niet elk verhaal over Mohammed dat later ergens is verteld heeft evenveel gezag. Maar in de Koran zelf telt elk woord. Toch studeert de islamitische theologie ook de uitlegtradities van de Koran en komen alle onderwerpen uit de geloofsinhoud aan de orde, de tafsir, en de methode van tafsir: usul oftewel theologische hermeneutiek. In de islam, geloofsvertrouwen en -gehoorzaamheid, hangt veel af van de waarheid van het geloof dat God tot Mohammed heeft gesproken en dat die woorden getrouw in de Koran zijn opgeschreven.

Historische kritiek heeft voor een godsdienstige traditie verstrekkende gevolgen. Zonder een degelijke historische basis zou het christendom - en veel ander geloof - in de lucht hangen en het grondig herzien moeten worden. Het zou een misschien sympathieke levensleer worden zonder historische basis. Romanschrijvers hebben deze denkmogelijkheid uitgebuit. $\mathrm{Zij}$ hoeven zich niets van wetenschap aan te trekken en kunnen schrijven wat ze willen, of het nu over het liefdesleven van Jezus en Maria Magdalena gaat of over vermeende reizen van Jezus door India. Ik ga niet op deze verhalen in. Veel belangrijker is de echte vraag: als niet alles letterlijk zo gebeurd is of hoeft te zijn, wat betekent dat dan voor de grond van mijn geloof?

Onze cultuur kent een merkwaardige tweespalt. Aan de ene kant is men postmodern, aan de andere kant vergt men harde en eenduidige bewijzen. In deze opvatting van rationaliteit en eenduidigheid worden alle geloofsvoorstellingen menselijke verbeeldingen. In wezen is het post-modernisme wat religie betreft dus niet post-modern maar modern: waar is wat iedereen kan inzien 
en we kunnen bewijzen; verder verbeelden we ons van alles, maar dat is niet rationeel. We zullen deze tweespalt van enerzijds algemeen aanvaarde kennis en anderzijds "ieder mag het zelf weten" moeten doorbreken.

\section{KRITISCHE VRAGEN OVER DE BIJBEL}

Het staat vast dat de bijbel de geschiedenis niet beschrijft zoals een huidige historicus dat zou proberen te doen: vaststellend wat er van stap tot stap precies gebeurd is. Lange tijd huldigden veel mensen de leer van de letterlijke inspiratie van de Heilige Schrift - mooi door Rembrandt geïllustreerd in het schilderij waar een engel aan de evangelist Matteüs de woorden die hij opschrijft influistert. Dat beeld stond voor de inspiratie van de bijbelschrijvers door de Heilige Geest. Toch waren er problemen met de letterlijke inspiratie. De eerste vijf bijbelboeken heetten weliswaar de vijf boeken van Mozes, maar hoe kon Mozes zijn eigen dood hebben beschreven? Erger nog, hoe kan hij zelf hebben genoteerd: "nu was Mozes een zeer bescheiden man - niemand op de hele wereld was zo bescheiden als hij” (Num 12:3)? Wie deze laatste vraag stelt, kan deze bijbelboeken al niet meer als een letterlijk dictaat van God aan Mozes opvatten. Men erkende dat een redacteur iets kon hebben toegevoegd (Aalders 1952:126-132; Spinoza 1997:239vv.). De discussies gingen natuurlijk dieper. Het ging over de zondeval — of de slang echt had gesproken - , de schepping in zes dagen, of de zon om de aarde draait, of Abraham echt heeft geleefd en ontzettend veel meer. De problemen waren de reden waarom men ertoe overging om van organische inspiratie te spreken: de Heilige Geest inspireerde de schrijvers van de bijbelse geschriften, maar ze waren zelf de "organen" die het vertelden. Daarmee zetten mensen als Abraham Kuyper de deur open voor andere interpretaties van de bijbelteksten. In de twintigste eeuw is deze "menselijke factor" steeds duidelijker geworden. Ook aan de orthodoxe kant van de kerk heeft men toegegeven dat de bijbelschrijvers veel sterker zelf betrokken zijn geweest in het componeren van hun verhalen dan mensen eerder hadden gedacht. De moeilijkheden logen er dan ook niet om. De schepping van hemel en aarde vanaf Genesis 1 tot en met de "oergeschiedenis" valt niet te rijmen met wat we over de totstandkoming van de aarde en het ontstaan van de mensen weten. Dit probleem kan men nog oplossen door over een vertellende scheppingstheologie te spreken: een uiterst zorgvuldig gecomponeerd verhaal van schepping en zondeval, dat over God, 
mens en wereld gaat maar uiteraard geen religieus biologie-boek is (Bavinck 1967:387vv.). Maar wat dan met gebeurtenissen die worden verteld maar waarvoor geen historische basis kan worden vastgesteld? Het oude Israël nam vlak na de intocht in Palestina Jericho in - maar nergens vond men resten van een stad die in die tijd was verwoest. Het kan geen historisch feit zijn. Er zijn merkwaardige ongerijmdheden in het geschiedverhaal: van David wordt bijvoorbeeld verteld dat hij het hoofd van Goliat naar Jeruzalem bracht - terwijl hijzelf later als koning Jeruzalem nog zal veroveren (Deurloo 1981:86)! Studies van bijbelgeleerden geven voorbeeld op voorbeeld van zulke historische "onnauwkeurigheden" - we kunnen het niet eens onnauwkeurigheden noemen want het is niet per vergissing zo geschreven. Twee van de vier evangelisten vertellen over de wonderlijke geboorte van Jezus, maar is Jezus van Nazareth wel in Bethlehem geboren of is ook dat historische verbeelding (Deurloo 1981:23)? De evangeliën vertellen elk een eigen verhaal over Jezus, maar het is niet mogelijk om de verslagen tot een uniform verhaal samen te voegen. Zijn ze dan wel betrouwbaar? Het ernstigste bezwaar tegen de bijbel als geschiedschrijving is, lijkt mij, dat het in heel deze geschiedenis van het begin tot het eind niet om louter feiten gaat maar dat de bijbel de geschiedenis en alle mensen waarover wordt verteld in een bepaald daglicht stelt. De geschiedenis van Israël wordt ten dele verteld, maar daar doorheen worden alle koningen tegen het licht gehouden en op hun gehoorzaamheid aan God beoordeeld. De rest doet er veel minder toe. Jezus' tegenstanders worden in een duister daglicht gesteld; Jezus' eigen opvattingen wijken op allerlei punten niet zo sterk af van die van de Farizeeën, maar ze worden zwart gemaakt als bittere vijanden. Kortom, de bijbel blijft niet bij de feiten, geeft feiten soms verkeerd weer en is niet neutraal maar ernstig vooringenomen. Wie kan zo'n boek geloven?

\section{ONHISTORISCHE GESCHIEDENIS}

Om deze kritiek kan niemand heen. Ik ga drie antwoorden op deze problematiek na. Eén serieus antwoord op de gegevens die de historische kritiek op de bijbel aan het licht heeft gebracht, is een ruimhartige erkenning van deze gegevens en een concentratie op de tekst van de bijbel als "openbaring." In deze benadering zegt men dat de bijbel geen geschiedenis in de moderne zin van het woord geeft. Dat geldt van de beide betekenissen van "geschiedenis": het historisch verloop en de wetenschappelijke reconstructie daarvan. 
Daarbij moet men bedenken dat de historische wetenschap grosso modo rond het jaar achttienhonderd is ontstaan en sedert de opgravingen in de tijd van de Romantiek een grote vlucht heeft genomen - en dan denken we aan het kritisch en systematisch uitzoeken wat er echt is gebeurd. Historische overzichten van de geschiedenis van Rome en van de christelijke kerk waren er overigens al in de klassieke oudheid en in de Renaissance, net als kritiek op de betrouwbaarheid van de bijbelse verhalen. $\mathrm{Na}$ de Verlichting heeft men geleerd zich veel strakker aan de feiten te houden, de bronnen heel kritisch te bestuderen en niet alles wat mensen beweren als waar te beschouwen (zie Kraus 1969).

De bijbel is namelijk een heel ander boek en geen "geschiedenis" in de zin van een op empirisch onderzoek van opgravingen en schriftelijke bronnen opgebouwd verslag van het historisch verloop waarmee elke onderzoeker — ongeacht diens geloof of ongeloof - kan instemmen. De bijbel is een boodschap. Sterker nog, de bijbel is een boodschap die deze wereld op de kop zet. De bijbel laat de lezer de wereld anders zien en pas in een meegaande beweging met de tekst kan de lezer verstaan wat deze tekst zegt. Op deze manier hebben een aantal protestantse theologen in het spoor van Karl Barth (gest. 1968) en Kornelis Heiko Miskotte (gest. 1976) een antwoord gezocht op de historische kritiek. Karel Deurloo (1981:15) noemt dat “onhistorische verhalen”. "Het overwegend ón-historische karakter van de bijbelse heilsgeschiedenis wordt in navolging van Barth, door de aanhangers van de nieuwe methode, zoals Miskotte, Breukelman en de zgn. Amsterdamse school volmondig toegegeven”, schrijft Nico T Bakker (1997:283). Die methode bestaat erin de historische kritiek gewoon te erkennen en zich op de tekst te concentreren. Het gaat in de bijbel niet om het historisch verloop maar om het leven, niet om de feiten zoals die exact zijn gebeurd maar om het leven zoals het is en wordt geleefd. Dat vergt wat ik zelf, min of meer in het spoor van HansGeorg Gadamer, een meegaande beweging noem.

Het is soms verhelderend om een zijstap te maken naar een andere religieuze traditie. Iemand die de eerste prediking van de Boeddha, in het hertenkamp bij Benares, leest en nauwkeurig uitlegt, kan natuurlijk een eind komen en aan de hand van overeenkomstige en alternatieve visies uit het India-Nepal uit de tijd van de Boeddha de tekst diepte geven en zo meer inzichtelijk maken. In deze prediking zet de Boeddha uiteen hoe een mens zich van allerlei 
verlangens - dorst - kan bevrijden, verleidingen niet alleen kan leren te weerstaan maar er ongevoelig voor te worden en zich zo los te maken van een wereld die voorbijgaand en niet genoegzaam is. De vraag is natuurlijk of we deze eerste preek van de Boeddha kunnen begrijpen als we niet aan onze eigen gehechtheden en gevoeligheden denken. Het is immers een tekst over het leven. De tekst zegt dat wie het leven wil begrijpen daar veel voor over moet hebben, zoals Prins Gautama het paleis, zijn vrouw en kind verliet en een zwervend leven ging leiden om uiteindelijk — als de Boeddha, de Verlichte - een uitweg te vinden uit een bestaan van schone schijn en ontkenning van de echte werkelijkheid. De vraag is natuurlijk wat voor "meegaande beweging" het van ons vergt om deze prediking te begrijpen. En: welke waarde heeft historischkritisch onderzoek naar deze eerste prediking van de Boeddha? Stel dat blijkt dat die preek zo nooit is gehouden maar dat het een later gevormde stilering is van wat de eerste discipelen van de Boeddha hebben doorverteld en van hoe de Boeddha zijn ervaringen van gehechtheid en de bevrijding van gehechtheid later aan meer mensen heeft uitgelegd? Nog dieper gaat de vraag of een uitleg van die prediking wel een echte uitleg ervan is, als ik niet zelf op zijn minst "even" met de ongenoegzaamheid van het "gewone leven" wordt geconfronteerd en me, opeens, mijn eigen vastzitten aan van alles en nog wat realiseer. Begrijp ik die tekst wel als ik niet een soort schok krijg waarin iets "zie" van hoe iemand die "verlicht" is in het leven staat? Uit de formuleringen die ik hier moet gebruiken om te verhelderen wat echt verstaan van de betekenis van die oude en klassieke boeddhistische tekst is, blijkt al dat het echte begrijpen van religieuze teksten niet buiten de lezer omgaat. De persoon van de lezer en hoorder is zelf in het geding en zonder openheid daarvoor kan een dergelijke tekst niet worden begrepen. Hieruit vloeit voort dat historisch onderzoek naar de context van de eerste prediking van de Boeddha uiterst verhelderend kan zijn voor het begrijpen van het nieuwe of eventueel zelfs minder nieuwe van de middenweg die de Boeddha zijn discipelen onderwees, maar dat een reconstructie van een historische gebeurtenis niet tot de kern van de religieuze gebeurtenis door kan dringen. Eerder zal literair-kritisch onderzoek naar oude boeddhistische prediking en vergelijking met brahmaanse tradities helpen om dieper in de tekst door te dringen. In zulk onderzoek van teksten worden allerlei nuances zichtbaar waardoor de lezer beter inzicht krijgt in verschillende aspecten van de levenshouding waarom het gaat. Vergelijkend onderzoek van oude 
teksttradities en de groei van klassieke formuleringen helpt tegelijk om zich een beeld te vormen van de ontwikkeling van de vroege boeddhistische tradities. Na deze korte schets van een parallel uit een andere religie keren we terug naar de barthiaanse en neo-barthiaanse reactie op de historische kritiek. Enerzijds kan deze vergelijking verduidelijken waarom het hen te doen is, anderzijds vloeit er wel een bezwaar uit voort, zoals ik straks zal laten zien.

Het sterke punt van de benadering van de zogenoemde Amsterdamse school - lange tijd de theologische stroming aan de Universiteit van Amsterdam - is de inzet bij de tekst als religieuze boodschap. Men kijkt niet van buiten de geloofstraditie naar de tekst maar probeert de tekst zelf te laten spreken als Woord van God een Woord dat mensen in beweging brengt. Het zogenaamde probleem van de historische kritiek lost men op door die kritiek te aanvaarden en eruit af te leiden dat het bijbelverhaal geen historisch verloop wil schetsen maar mensen anders in het leven zet. Omdat de bijbel prediking is, is het onhistorisch (in moderne zin). Wie de bijbel wil uitleggen, moet dus niet als een historicus te werk gaan maar als een exegeet die de tekst nauwkeurig leest en juist aan de nuances en ongerijmdheden afleest wat de tekst zegt. De bijbel is boodschap. Afstandelijk onderzoek gaat aan de strekking van de tekst voorbij. Langs deze lijnen schrijft Karel Deurloo (1981:27): "Onhistorisch behoeft niet te betekenen: onwaar. Sterker nog: het onhistorische kan nodig zijn om waarheid uit te zeggen, die historisch niet onder woorden is te brengen”. Het is geen historisch, maar bijbels realisme, dat in de bijbels soms dichtbij historische gebeurtenissen ligt, zich er soms ver van verwijderd en er soms nauwelijks meer een relatie mee heeft (Deurloo 1981:84) Juist door ongerijmdheden komen we de betekenis van een tekst op het spoor. Deurloo geeft een voorbeeld uit het verhaal van David en Goliat dat we in de inleiding op de hoofdstuk al noemden - een kleine jongen die niemand kende verslaat de grote reus. "David nam het hoofd van de Filistijn en bracht het naar Jeruzalem”, vertaalt hij (Deurloo 1981:15; 1 Sam 17:54). Dat kan niet gebeurd zijn, want Jeruzalem werd pas later ingenomen om vanaf dan als hoofdstad te dienen. De schrijver van deze geschiedenis wist dat als geen ander. Door deze historisch onjuiste beschrijving legt de schrijver een verband tussen de ongelijke strijd van klein en groot, zwak en machtig en de stad van de vrede. Als we de betekenis van Jeru-sjaloom, stad van de vrede, bedenken, en dan onwillekeurig de beelden van aanslagen, 
soldaten, ontoegeeflijke politici, verdwaasde zelfmoordenaars, slachtoffers en lijken, veel lijken, voor ogen zien, dan gebeurt precies wat deze tekst bedoelt - schrijf ik vrij in de lijn van deze stroming. Als we deze beelden in contrast zien, ontstaat er een breuk tussen hoe de wereld zou moeten zijn en hoe de wereld is. Zo predikt deze merkwaardige tekst aan het eind van het verhaal over David en Goliat hoe het zwakke het sterke overwint en hoe Jeruzalem de stad van de vrede kan zijn. In het verlengde hiervan ligt wat Paulus later aan de christenen in Corinthe schrijft, dat het dwaze van God wijzer is dan mensen (1 Cor 1:25). Steeds gaat het in de bijbel om een beschrijving van het leven die bij de lezer en hoorder een ommekeer teweeg brengt. Waar de bijbelschrijvers een grijs verleden beschrijven en daarvoor historische stof gebruiken, vormen ze historische stof om ten einde Gods stem in het gebeuren te laten 'horen' (Deurloo 1981:102, vgl. 97, 101, 73vv.). De bijbelse geschiedenis die verteld wordt is geen academische historie maar "vertellende theologie", zoals het verhaal over Israëls ongeloof en de verering van een gouden kalf op het moment suprême van Israëls bestaan: God sluit met Mozes het verbond - maar aan de voet van de berg mort het volk en maakt het een god die het met eigen handen kan dragen waar het wil (Deurloo 1981:76; Ex 32). De verscheurende hardheid van deze tegenstelling tussen de genadige (echte!) God die in een ontoegankelijk licht woont maar zich een volk toewendt om het recht en barmhartigheid te leren, wordt door de tekst opgeroepen en is tegelijk voorwaarde voor dieper, echt, verstaan. Daarom legt de barthiaanse, en ruimer de gereformeerde, theologie zoveel nadruk op de kracht van het Woord van God dat in een geloof wordt gehoord - geloof dat het zelf oproept. De Nederlandse geloofsbelijdenis belijdt de begrijpelijkheid van de bijbel, de claritas ervan. Die betekent niet dat iedereen direct alles begrijpt en ook niet dat de beste schriftgeleerde elke tekst zou kunnen uitleggen, maar — zoals de Confessio Belgica in artikel 7 zegt — dat in de bijbel datgene duidelijk is wat wij voor onze zaligheid nodig hebben. Wat mensen nodig hebben, is een omwenteling in hun verstaan van het leven.

Uit deze beschrijving van dit "antwoord" op de historische kritiek blijkt al wel dat ik er op veel punten mee instem. Wat mij betreft blijft de vraag wat nu de relatie is tussen de echte geschiedenis en de vertellende theologie. Wat is nu het verschil tussen religieuze verbeelding met een historische enscenering en 
heilsgeschiedenis? ${ }^{2}$ Voor wie gelooft of niet gelooft lijkt me de kritische vraag of deze verbeelding willekeurig is of niet. Hangt deze verbeelding in de lucht of heeft ze een historische basis? Op dit punt ligt het voor een boeddhist anders dan voor een jood of een moslim of een christen. Mij dunkt dat een boeddhist over de eerste prediking van Boeddha voor zijn leerlingen kan zeggen dat het kan vriezen of dooien, maar dat de "proof of the pudding is in the eating": het verhaal is met wat variaties in elk geval heel oud en het geeft ook de kern aan van het originele boeddhisme en of het echt zo gebeurd is, is een historisch interessante maar religieus onbelangrijke vraag. Maar een moslim zal niet zo gemakkelijk kunnen zeggen dat het er niet toe doet of God feitelijk op zeker moment in de geschiedenis tot Mohammed de woorden heeft gesproken die in de Koran staan opgetekend. Een orthodoxe Jood in het oude deel van Jeruzalem zal niet gemakkelijk kunnen zeggen dat het verhaal van de Verbondssluiting op Sinaï en de belofte van het land aan Israël op religieuze verbeelding alleen berusten. Deze twee voorbeelden maken tegelijk de praktische en politieke lading van de historische kritiek duidelijk: het gaat om veel meer dan academische vragen. Mensen handelen op grond van deze "verbeelding" met alle goede en schrikbarende gevolgen van dien. Daarom staat de term "verbeelding" mij tegen en mag men "verbeelding" ook niet afschermen van kritische reflectie en kritische dialoog. Wat is de relatie tussen de "geschiedenis als vertellende theologie" en de feitelijke geschiedenis? Karel Deurloo schrijft: "Het verhaal van David en Goliat, hoe onhistorisch ook, slaat op de reële geschiedenis van Israël en speelt in het niet minder reële land, dat Israël mag bewonen. We lezen het verhaal niet om kennis te nemen van een mooie, boventijdelijke wijsheid, maar om ons vandaag de dag te laten bemoedigen" (Deurloo 1981:13). Juist deze verwijzing naar de bemoediging voor het huidige leven maakt de verantwoording van

2 De term verbeelding is sinds het begin van de jaren negentig populair geworden om de aard van godsdienstig taal en beeldvorming aan te duiden. De wortels van dit spreken liggen in Hegels denken en het Neo-Kantianisme, maar er komen ook belangrijke aanzetten uit de taalfilosofie van Martin Heidegger en Ludwig Wittgenstein. Zie bijv. Garrett Green (1989); over de religietheorie op basis van de verbeelding and John Hick's seeing-as, bijv. Desiree Berendsen (2001); over de (verwante) spanning tussen beschrijven en begrijpen, bijv. Peter Jonkers, en René van Riessen (2004). Voor een uitwerkingen in de lijn van Wittgenstein leze men recente publicaties van D.Z. Phillips (gest. 2006). 
dit onhistorisch verhaal dat het leven laat zien met de omkering van "de orde van deze wereld” urgent. De verwijzing naar "het land, dat Israël mag bewonen" zal voor huidige Palestijnen anders klinken dan voor huidige Joden. Welke historische basis heeft de landbelofte? En wat is de betekenis ervan dat het kleine goede beter in staat is het grote kwaad te verdrijven dan een even machtig "goede" (dat altijd weer in zijn tegendeel verkeert)? Waarvoor staat David en waarvoor Goliat? Wat bedoelde men toen men dat opschreef en hoe lezen de huidige bewoners van Jeruzalem het verhaal? De vraag naar de geloofsverantwoording kan en mag niet van tafel worden geveegd door wat voor gelovige oproepen dan ook. Voor christelijk geloof maakt de historische vraag deel uit van de geloofsverantwoording.

Op dit punt is de barthiaanse theologie kwetsbaar. Pregnant komt dat uit in de beschouwing van Nico Bakker (1997:284v.) waarin hij zijn slotparagraaf als opschrift meegeeft: "Historiciteit praktisch nul"! De openbaring staat haaks op de mensengeschiedenis en breekt daarin onverwacht en onnavolgbaar in. "Zij maakt aanspraak op een bijzondere historiciteit” (Bakker 1997:284-6). Het raakt ons en gaat ons allerintiemst aan maar heeft een eigen, bijzondere historiciteit. Het is "een gebeuren sui generis, waarin waarheid en werkelijkheid samenvallen.” Bakker legt de waarheid dus in het effect van de realiteit van mensen die door het Woordgebeuren worden geraakt. Juist door dat effect wordt geloof echte geschiedenis. In die zin maakt de bijbel geschiedenis. Goed geloof blijkt in goed leven - dat zal betekenen dat dan de feitelijke mensengeschiedenis ook iets beter wordt. Als Bakker zegt dat het Woord van God steeds inbreekt in onze werkelijkheid, staat hij pal naast Karl Barth in de eerste delen van de Kirchliche Dogmatik. Daarin vergelijkt Barth $(1932: 114 ; 1938: 589)$ de inslag van het Woord van God met de engel, die in het bijbelverhaal op onvoorspelbare momenten neerdaalt in het badwater van Betesda. Wie er tegelijk met de engel in is, wordt genezen. Men heeft dat het actualisme van Barth genoemd (Schlichting 1971:172; vgl.Vroom 1978:94). Mijn bezwaar daartegen is dat er zo geen plaats is voor een stil en getrouw en duurzaam geloof. De openbaring wordt een blikseminslag die deze wereld raakt en verandert maar er zelf toch nooit deel van uitmaakt. Deze kritiek geldt ook de opvatting van Nico Bakker. De bijbel verwijst naar echte geschiedenis, schrijft Van der Woude (1997:287-290); God deelt met ons de tijd, schrijft Van der Brom (1997:335vv.). 
Terecht legt men in deze stroming veel nadruk op het tegendraadse van de bijbelse openbaring en even terecht aanvaardt men de resultaten van historisch-kritisch onderzoek. Het probleem is dat men zo'n grote tegenstelling maakt tussen openbaring en geschiedenis dat het geloof zijn basis in de geschiedenis verliest en een willekeurige religieuze verbeelding dreigt te worden. Ik kom daarop terug, maar bespreek eerst de tegengestelde benadering die ervan uitgaat dat de bijbel bestudeerd moet worden als alle andere literatuur.

\section{ALS ALLE ANDERE LITERATUUR}

Veel bijbelwetenschappers aan de klassieke westerse universiteiten zeggen dat de bijbel bestudeerd moet worden zoals alle andere geschriften. Elke andere benadering plaatst de onderzoeker buiten de wetenschap. In feite geeft men zo hetzelfde antwoord als de bijbelwetenschappers van zoëven: de historische kritiek op de bijbel is zoals ze is; veel van wat de bijbel verteld, is niet gebeurd zoals het er staat; de verhalen zijn sterk geredigeerd en gecomponeerd en zijn vanuit een geloofsstandpunt partijdig opgeschreven. Als gevolg daarvan kunnen we niet neutraal en rationeel weten wat er precies en echt is gebeurd. Dat betekent dan weer dat elke religieuze uitleg van de bijbel - en welk andere geschrift dan ook - altijd een persoonlijk oordeel inhoudt dat alleen binnen een bepaalde traditie bespreekbaar en enigermate toetsbaar kan zijn. Nu mag iedereen geloven wat hij wil en zich door allerlei verhalen aangesproken voelen, maar dat valt wel buiten de wetenschap.

Uiteraard kan neutrale wetenschapsbeoefening niet aantonen dat er een historische basis is voor het geloof dat God zijn hand heeft gehad in de geschiedenis van de mensheid en in het bijzonder in de geschiedenis van het volk Israël, of dat de Heilige Geest de christelijke kerk leidt en behoedt in turbulente historische verwikkelingen. Er is trouwens niemand die precies kan zeggen hoe dat gaat! De verwijzing naar God valt buiten wat neutraal bewezen kan worden, zoveel is duidelijk. Daarmee is natuurlijk niet alles gezegd, want het gaat niet om een godsbewijs maar om een historisch minimum dat in jodendom en christendom wordt voorondersteld (Van der Kooi 1997:302). Wil de Bergrede gezag hebben, dan moet aannemelijk zijn dat Jezus gepreekt heeft en zulk soort dingen heeft gezegd. Hoe verder weg in het verleden, des te moeilijker zijn historische beweringen hard te maken. Wat dat betreft 
ligt het voor het Nieuwe Testament gemakkelijker dan met de delen van het Oude Testament die handelen over de tijd van voor de ballingschap. Jezus heeft geleefd, heeft opvattingen gehad die men behoorlijk in kaart kan brengen en is ter dood gebracht om wat Hij zei en deed. Op grond van verschijningen waren zijn volgelingen overtuigd van Jezus' opstanding. Ik ga voorbij aan de oude discussie of bewijsbaar is dat het graf waarin het lichaam van Jezus was gelegd op de ochtend erna leeg was. Hoe interessant de discussies over de historiciteit van specifieke bijbelverhalen ook zijn, hiermee is in vaststelbare feite gezegd dat voor de historische basis van geloof in Jezus niet zo heel erg veel feiten nodig zijn. Voor uiterst belangrijke elementen van de joodse en de christelijke traditie zoals de roeping van Abraham en Sara, de uittocht uit Egypte en de verbondssluiting op de Sinaï zijn uiteraard nauwelijks bewijzen te leveren. Daar moet men het met de verhalen doen. Die verhalen hebben, technisch gesproken, "fictionele elementen", zoals Edwin Koster (2005:320) het in zijn brede studie "over verhaal en rationaliteit, religie en irrationaliteit”, In betovering gevangen?, uitdrukt. Het gaat over geschiedenis, maar tegelijk over het leven en over God. Het is geen gewone geschiedenis en anders dan veel literatuur gaat het expliciet over God, mens en wereld. Daarom is het "fictionalized history en historized fiction": "In bijbelverhalen komen het historische en het fictionele karakter samen. Bijbelverhalen hebben zowel de pretentie te laten zien wat essentieel was in het verleden als het vermogen de wereld te onthullen. Daarmee bezitten ze de essentiële functies van geschiedverhalen en fictionele verhalen. Wat de fictionele verhalen betreft, gaat het ... om het vermogen een mogelijke wereld in het leven te roepen, de wereld van het verhaal" (Koster 2005:320). De bijbelverhalen staan dus in een religieuze traditie. Men kan die verhalen alleen goed uitleggen als men met allerlei literaire gegevens van het Hebreeuws en Grieks rekent, met de diverse historische contexten waarin de "schrijvers" van de bijbelboeken leefden en met de geloofsvoorstellingen die zij aan hun voorgangers ontleenden. Uitleg vergt dat men met de diverse aspecten van de teksten rekent, en dus met taalkundige, literaire, sociaal-economische, en religieuze aspecten in de steeds wisselende historische contexten. Als het niet mogelijk is vast te stellen wat er precies is gebeurd en als tegelijk duidelijk is dat het beeld van het verleden meer fictionele geschiedenis is naarmate het verder in het verleden ligt (Leene 1999:78v.), dan kan "geleerde" 
bijbeluitleg toch de teksten doen oplichten en inzichten over God, mens en wereld tonen die ook nu betekenisvol zijn.

De leus van veel bijbelgeleerden dat de bijbel bestudeerd moet worden zoals alle andere geschriften lijkt mij zowel juist als onjuist. Het is in zoverre juist dat er geen gelovig hek om de bijbel geplaatst moet worden waarmee bepaalde vragen worden afgeschermd. Maar tegelijk is het te algemeen gesteld. Het klopt mijns inziens niet met wat de bijbelwetenschap zelf kan doen. Elk onderzoek wordt bepaald door het onderwerp van studie. Studie van de Koran zal nooit exact hetzelfde zijn als studie van de bijbel, want de Koran is een heel veel kortere tijd ontstaan. Studie van de hindoe geschriften zal op allerlei manieren lijken op de studie van bijbelse geschriften maar de vraag naar historische reconstructies ligt daar heel anders. De onderzoekers kunnen wel "dezelfde methoden" hanteren, maar de benadering die de teksten zelf nodig hebben zal per religieuze traditie verschillen. In dit perspectief kan de opmerking dat de bijbel precies zoals alle andere geschriften moet worden bestudeerd gemakkelijk een seculiere strijdkreet worden in plaats van een zorgvuldig overwogen wetenschappelijke uitspraak. Historisch en literair onderzoek naar de bijbelse teksten heeft onvermijdelijk te maken te maken met de boodschap in de tekst over Gods hand in en achter wat gebeurt. Bijbelwetenschappers kunnen Gods ingrijpen uiteraard niet bewijzen, maar de strekking van de teksten ook niet negeren. Ook dat vloeit voort uit de regel dat men de bijbel moet besturen zoals andere geschriften. Dat moet men bij de uitleg van de gesprekken van de Boeddha, de spreuken van de hindoe zieners, Mohammeds getuigenis dat hij woorden ontving van God en dus ook bij de joodse en christelijke geschriften. De vraag of het godsdienstig karakter van de bijbelse geschriften een rol mag spelen is dus gemakkelijk te beantwoorden. Als elk onderzoek zich naar het voorwerp van onderzoek richt, dan mag de bijbel niet anders worden bestudeerd dan als religieus geschrift-daargelaten dat men de bijbel ook voor andere doeleinden kan lezen, zoals voor welke planten er worden genoemd of wat voor wereldbeeld men had, afgezien van de idee dat de wereld geschapen is. Als de bijbel als verzameling godsdienstige geschriften wordt bestudeerd, is de volgende vraag of deze studie zuiver godsdienstwetenschappelijk moet zijn of dat de bijbelwetenschap ook theologisch mag zijn. Mag een exegeet onderzoeken wat - gezien binnen de joodse en de christelijke tradities - God tot mensen heeft gezegd? Leene meent dat dit 
legitiem is. Een exegeet gaat niet ineens andere methoden gebruiken, maar kan de historisch-kritische methode inzetten uit interesse voor het spreken van God. Die interesse maakt het onderzoek niet onwetenschappelijk. Elke uitlegger heeft een doel en kiest de voor dat doel geëigende middelen (Leene 1999:85). Leene verwerpt het onderscheid tussen een betekenis die de tekst in de horizon van het verleden zou hebben (die het doel van bijbelwetenschappelijk onderzoek zou zijn) en betekenis die de tekst vandaag voor mensen of groepen heeft of kan hebben. Hij vindt dat onderscheid kunstmatig.

Vanuit de hermeneutiek gezien is een scherp onderscheid inderdaad niet te handhaven. Zoals in de vorige paragraaf is beschreven, vergt uitleg een "meegaande beweging". De vraag is of de betekenis die de auteurs hebben bedoeld over te brengen, echt begrepen kan worden zonder zich al was het maar voor een moment in te beelden dat de tekst waar is, dat wil zeggen: waarheid aan het licht brengt. Om deze reden gebruikt men in de hermeneutiek vaak de uitdrukking "het gesprek tussen tekst en lezer”, waarbij in zekere zin niet alleen de tekst maar ook de lezer wordt 'uitgelegd'. Ik heb dit punt wel eens uitgewerkt aan de hand van een hindoe gedicht, waar van de godheid wordt gezegd: hij at me op met huid en haar en vervulde mij, veranderde mij in hemzelf (Nammalvar 1993:96; vgl. Vroom 2003:53vv). Om te begrijpen wat "veranderde mij in hemzelf" betekent, moet ik niet alleen meer weten van hindoeïsme en van de specifieke stroming waaruit dit gedicht is voortgekomen, maar mij ook proberen te verplaatsen in iemand voor wie dit geloof werkelijkheid is. Pas als ik de werkelijkheid anders zie, zoals die traditie die voorstelt, kan ik het gedicht dieper begrijpen. Dat geldt ook van de uitspraak van Paulus over wat hij goed deed: "ik zelf leef niet meer, maar Christus leeft in mij” (Gal 2:20). Om te weten wat voor soort iets dat zou kunnen zijn, moeten we ons niet in Paulus verplaatsen maar als het ware Christus in ons - dat is nogal confronterend. Als iemand nu zou zeggen dat die confrontatie en verbeelding buiten de wetenschap valt en dat wetenschap alleen gaat over "What is meant", dan begrijp ik niet meer wat deze afstandelijke wetenschap eigenlijk nog uitlegt. Als Paulus in een van zijn brieven over de opstanding der doden schrijft, roept hij uit dat wij, als wij alleen voor dit leven op Christus hopen, en Hij niet is opgestaan, wij de beklagenswaardigste mensen zijn die er bestaan. Om dat echt te begrijpen moeten we ons afvragen waarom dit voor 
hem zo zou zijn en ons indenken hoe zijn wereld in elkaar zou storten als Christus niet was opgewekt (en wij dus God niet zouden kennen in Christus) (1 Cor 15:19). Wie deze tekst leest zonder de schok enigszins na te voelen zoals Paulus die beschrijft, gaat in feite aan de tekst voorbij. Maar dat brengt met zich dat we ons bij het lezen van de bijbel moeten voorstellen dat God bestaat, de wereld heeft geschapen en achter alle dingen staat — op manieren die wij niet kunnen doorgronden. Als ik mij dat niet voorstel, begrijp ik niet wat de tekst zegt. Daarom is het onderscheid tussen een betekenis die de tekst in de horizon van het verleden zou hebben en betekenis die de tekst vandaag voor mensen of groepen heeft of kan hebben kunstmatig. De tekst confronteert de lezer met een inzicht dat waar, ten dele waar of onwaar is. Net zo min als een ander kan een exegeet bewijzen dat God in de bijbel spreekt, maar wel kan de bijbelwetenschap uitleggen wat de teksten betekenen als ze waar zouden zijn. Voor iemand die gelooft dat de tekst - op een manier die voor ons niet doorzichtig is - van God komt, betekent dit dat de bijbeluitleg wel degelijk het woord van God kan doen oplichten. Als men de ongenuanceerde strijdkreet laat vallen dat de bijbel moet worden uitgelegd als elk ander boek en erkent dat elk lezen "een gesprek tussen tekst en lezer" inhoudt en de uitleg dus bepaald wordt door de inhoud van de tekst en het onderwerp van het "gesprek", dan vervalt vanzelf de eis dat geloof geen rol mag spelen in de bijbeluitleg. Iemand die niet gelooft, brengt diens irreligiositeit mee en iemand die gelooft diens geloof en beiden worden door de tekst uitgedaagd het leven te zien zoals de tekst zegt.

\section{DE BETROUWBAARHEID VAN DE BIJBEL}

In de tweede paragraaf hebben we gesteld dat we ons voor het vertrouwen dat de bijbel waar inzicht biedt, niet alleen op geloof in de bijbel kunnen beroepen. In de derde paragraaf hebben we een benadering die de subjectieve factor in de uitleg niet genoeg ruimte geeft, afgewezen. Maar als ieders eigen opvatting een rechtmatige rol speelt in de uitleg van de bijbel, blijft toch de vraag of de historische kritiek de betrouwbaarheid van de bijbel niet ondermijnt.

Aan de hand van enkele voorbeelden van uitleg van de nieuwtestamenticus Tjitze Baarda zal ik nu op de betrouwbaarheid ingaan - Baarda heeft daarover in een eerdere discussieronde over dit onderwerp een boekje voor gemeenteleden geschreven (1967a). Hij geeft talloze voorbeelden. Baarda geeft een fraaie uitleg van een 
gebeurtenis die verhaald wordt in Jozua 10:12-15. De Israëlieten moeten slag leveren met de Amorieten. Eerst wordt de veldslag weergegeven. God strijdt aan de kant van Israël; hij zorgt voor paniek in de gelederen van de vijand en zendt later hagelstenen die meer vijanden doden dan de Israëlische soldaten. Maar dan grijpt het verhaal terug en vertelt dat Jozua een gebed had uitgesproken: "Zon, sta stil boven Gideon; maan, blijf staan boven de vlakte van Ajjalon." "En de zon stond stil en de maan bleef staan tot Israël zijn vijanden had afgestraft." De schrijver maakt vervolgens nog duidelijk dat hij weet dat dit niet kan; het is nog nooit voorgekomen dat God op die manier gehoor gaf aan iemands bede.

Voor de meeste mensen zal deze tekst geen probleem opleveren, want we verklaren de voorstelling dat de zon om de aarde draait uit een verouderd wereldbeeld. Om het verhaal te redden heeft men het wel zo gelezen alsof de aarde heeft stilgestaan en niet om zijn as is gedraaid. Natuurlijk is het ook onvoorstelbaar dat de aarde niet om haar as draait. De fout van deze strategie om een onbegrijpelijkheid in de bijbel "op te lossen" is dat het verhaal zelf niet meer wordt gevolgd. Wie het hele verhaal leest, ziet dat de poëtische verzen 12-15 er niet in passen; het moet later zijn ingelast. Er staat bij de hierboven geciteerde dichtregels dat ze staan opgetekend in het Boek van de Oprechte, blijkbaar een ouder geschrift waaruit ook in een ander bijbelboek wordt geciteerd. Het Oude Testament kent veel meer liederen waarin gebeurtenissen worden bezongen. Kennelijk heeft de verteller van het verhaal enkele regels uit het lied waarin deze veldslag werd bezongen in zijn tekst ingevoegd. De uitleg krijgt nog een nieuwe wending, want de schrijver leefde in een tijd met nog weer een ander wereldbeeld dan dat van zijn teksten, waarin de hemellichamen niet als fysische objecten werden gezien die hun wiskundig beschrijfbare banen door de hemel trokken maar vol waren van kosmische krachten en goden. Zon en maan zijn voor de oude Egyptenaren en Babyloniërs de belichaming van goden. In dit verhaal blijkt nu dat deze goden onderworpen zijn aan God, die de Israëlieten helpt. De kosmos met zijn bedreigende krachten is ontgoddelijkt. Wie op God vertrouwt is veilig. Baarda (1968:45) vraagt zich af of het lied nog meer wil zeggen en beantwoordt die vraag met: "maar het zegt al zoveel, het zegt eigenlijk alles". Dit lied wordt ingevoegd in het verhaal, maar in het verhaal heeft de verteller alweer een ander wereldbeeld, waarin de zon alleen lichtdrager is. Daardoor wordt het ook een ander 
wonder: een mens bidt dat de zon stilstaat en dat gebed wordt verhoord. Zo zien we dat de onderscheiding van verschillende lagen in het verhaal de teksten niet stuk maakt maar meer aspecten van de gepredikte werkelijkheid aan het licht brengt. Al te vlugge aanpassingen van het verhaal aan onze context verliezen deze boodschappen gemakkelijk uit het oog.

Kan men in onze tijd dit verhaal "geloven"? Ik denk: ja en nee. Niet als we het als letterlijke gang van zaken lezen en ook niet als we proberen het te 'vertalen' in een 'beter' beeld van hoe de wereld in elkaar zit. Kunnen we zulke verhalen niet beter lezen, meent Baarda, als een kind, onbevangen lettend op de kern van de boodschap en de geloofservaring die erin ligt besloten? Temidden van de machten van deze wereld heerst God en de mens mag daar vrij in staan.

Wat Baarda hier in feite doet is de Schrift uitleggen vanuit de compositie van het hoofdstuk, waardoor de boodschap oplicht en de moeilijkheid voor de moderne lezer - hoe kan de zon om de aarde draaien en stilstaan? — niet kunstmatig wordt "gered" door een herinterpretatie maar in die tijd als mogelijkheid wordt begrepen. In feite valt dat wonder anders weg en rest de verwondering over het succes van hun zegetocht.

Als tweede voorbeeld neem ik een kleine passage die zou hebben kunnen plaatsvinden zoals ze wordt verteld. Iemand komt naar Jezus toe en vraagt hem dat hij diens broer aanmaant om de erfenis met hem te delen. Jezus antwoord klinkt bars: "Wie heeft mij als rechter of bemiddelaar over jullie aangesteld?”(Lk:12:13v.). Vervolgens waarschuwt Jezus de discipelen voor hebzucht en rijkdom. In vertrouwen op God mogen ze onbezorgd leven: Verkoop je bezittingen en geef aalmoezen. Wat betekent zo'n fragment? Het volgt op een andere uitspraak van Jezus over onbezorgdheid: als men je het vuur na aan de schenen legt, vrees niet, maar vertrouw erop dat de Heilige Geest je de juiste woorden in de mond zal leggen. Het evangelie is geen historisch-wetenschappelijk verslag maar een getuigenis dat probeert de kern over te brengen. Kan het zijn dat Lucas tussen de beide korte redevoeringen over onbezorgdheid, de diepte van geloofsvertrouwen en de ernst van verdrukking en vervolging - waaronder zoveel christenen ook in onze wereld leven - een contrast schept door te vertellen hoe iemand Jezus wil inschakelen als een autoriteit die hem kan helpen zijn materiële 
zaken te regelen (Baarda 1969, vgl. 1967b)? De exegeet kan nog op andere manieren licht proberen te werpen op de tekst, zoals door vergelijking met verwante verhalen en stille verwijzingen naar het Oude Testament (er bestaat hier een scherp contrast met 2 Sam 15:4).

Maar wat is nu eigenlijk het doel van de exegese? Baarda ziet het als de verheldering van het lijnenspel in en rond de tekst zodat de bijbelpassage de lezer kan aanspreken. Voor een bijbelwetenschapper die werkt binnen de cirkel van synagoge of kerk zal het erom gaan de tekst zo te verhelderen dat de tekst als woord van God de lezer toespreekt. Baarda benadrukt twee aspecten. Ten eerste, de evangeliën hebben de vorm van verhalen, die worden verteld vanuit het werkelijkheidsbesef van de vertellers en hun voorgangers, met het beeldend vermogen van de vertellers (en niet van onderzoekers die feiten willen vaststellen die geen mens kan ontkennen). Ten tweede, ze vertellen geen geschiedenis zonder meer, maar ze vertellen over de beslissende dimensie in het leven, Gods genadige aanwezigheid in Christus (Baarda 1967b:23; vgl. 1966:m.n.102vv.). De vraag naar de betrouwbaarheid van de bijbel moet zich richten naar de bedoeling van de bijbelboeken. Het is een rationalistische valkuil om een vooropgezet idee van historische betrouwbaarheid te hebben en die de bijbel op te leggen. Zulke vooropgezette methodische criteria bepalen wat de agnost betreft een negatieve uitkomst maar voor de fundamentalist een positieve. In een geloofsact aanvaardt de fundamentalist de onfeilbaarheid van de bijbel en de "letterlijke" historiciteit van het scheppingsverhaal en een heel aantal andere bijbelse inzichten (en dogmata). ${ }^{3}$ Maar de agnost wordt bevestigd in zijn idee dat religie nergens op gebaseerd is. De criteria voor geldige kennis die men hanteert zijn echter eenzijdig (vgl. Vroom 2006, hfd.st.3). De regel dat men de bijbel gelijk moet behandelen als alle andere geschriften, houdt niet in dat men de bijbel net zo leest als een wetenschappelijke verhandeling over het verloop van de Tachtigjarige Oorlog of een verzameling Griekse en Romeinse sagen en legenden. Integendeel, de methoden van uitleg moeten passen op het voorwerp van onderzoek, een heilig geschrift van een godsdienstige traditie, waarvan de inhoud getuigt

3 Het is hier niet de plaats om uitvoerig in te gaan op fundamentalisme. De term fundamentalisme duidt op een selectie van waarheden die men (met zwaar geschut) tegen anderen verdedigt; cf. Almond c.s. (2003). 
van het leven voor Gods aangezicht. Het is bovendien een geschrift uit een andere tijd en cultuur met een ander begrip van geschiedenis. De godsdienstige verhalen bedoelen de lezer met andere ogen te laten kijken, zoals we in de paragraaf over Karel Deurloo c.s. zagen. Voorzover ik weet, geldt dat van alle grote religieuze tradities: de waarheid is anders dan wij meestal denken en vergt een ommekeer, een verandering van blikrichting, een bekering of een onthechtingsproces (Vroom 1988:228-230). Daaruit volgt dat de waarheid van zulke religies niet algemeen inzichtelijk is in de zin dat ieder het zondermeer kan inzien. Tradities maken er intussen wel aanspraak op dat ieder de waarheid van hun inzichten zou kunnen inzien.

De waarheid waar het in de bijbel om gaat is betrouwbaar inzicht in het menselijke bestaan in samenleving en geschiedenis en God als de Schepper van hemel en aarde en zijn handelen in de geschiedenis. Om de betekenis van deze teksten te 'decoderen' wordt meer van de lezer gevraagd dan het vaststellen van grammaticale constructies en woordbetekenissen en reconstrueren van historische situaties. De lezer moet zich open stellen voor de mogelijkheid dat de tekst waarheid aan het licht brengt en de wereld laat zien zoals ze echt is. Teksten over de aard van het mens-zijn kan men niet begrijpen als men ze alleen afstandelijk leest. Men kan ze op die manier ook niet beoordelen. Als men een dergelijke weergave van geschiedenis afwijst is dat niet omdat er historische feiten niet kloppen - David brengt het hoofd van Goliat naar Jeruzalem! maar omdat men het beeld van de werkelijkheid dat wordt getekend niet gelooft. Deze geschiedenis is tegelijk verkondiging van een wereldbeeld. Als men niet gelooft dat God de wereld gemaakt heeft - op manieren die wij mensen niet kunnen doorgronden en al helemaal niet narekenen - is dat niet omdat de wereld niet in zes dagen ontstaan is maar omdat men niet in een Schepper gelooft.

Omdat de bijbelse geschiedenis verhaalt van Gods omgang met mensen en het leven van mensen met elkaar in hun omgang of nietomgang met God (en elkaar) kan de "echte" geschiedenis niet uit het verhaal worden gepeld. Die geschiedenis van God en mensen is de echte geschiedenis en elke reductie ervan tot constateerbare feiten waarover allen het eens zouden kunnen zijn doet tekort aan het bredere verband waarin mensen leven. Daardoorheen loopt dan nog dat het in de bijbel er meer om gaat een beeld van het leven te schetsen dan exacte feiten te noteren. Om het met Wessel Stoker te 
zeggen: "bijbelse verhalen zijn geen fictie, evenmin geschiedenis in de gebruikelijke zin van het woord. Het gaat om history-like verhalen over Gods omgang met mensen in de loop der tijden, waarbij de verteller ook sagen en legenden gebruikt"4

Wat heel zwaar moet wegen is dat een historicus bij teksten die vertellen hoe God ingrijpt in mensenlevens of de geschiedenis leidt, die teksten uiteraard niet kan controleren. De "controle" van de geloofwaardigheid van historische bronnen berust op criteria zoals de veelheid van getuigenissen die elkaar ondersteunen, een algemeen oordeel over de betrouwbaarheid van documenten als historische bronnen, de waarschijnlijkheid dat iets heeft plaatsgevonden en daarmee een oordeel over wat men denkt dat wel en niet mogelijk was en is. Ernst Troeltsch heeft deze criteria ooit geformuleerd als kritiek, analogie en correlatie. Kritiek zegt dat we bronnen kritisch moeten lezen en niet alles als waar gebeurd aanvaarden. Sagen en legenden vat men niet als bronnen voor gebeurtenissen op maar wel als bronnen voor een beeld van een toenmalige cultuur. Historische geschriften van de hand van medewerkers van de koning beschouwt men niet als onafhankelijke geschiedschrijving. Van evangeliën die de betekenis van Christus willen laten zien, neemt men op voorhand aan dat ze een gekleurd beeld geven. Het principe van de analogie helpt om te beslissen wat gebeurd kan zijn en wat niet. Wat overeenkomt met wat gewoonlijk gebeurt, kan gebeurd zijn; wat nooit gebeurt en altijd weer een onwaar verhaal blijkt als men het in de eigen tijd controleert, kan ook in het verleden niet hebben plaatsgevonden. Laten we enkele voorbeelden noemen. De leeuw en het bokje leven nu niet lang vredig samen in een hok, en dus tweeduizend jaar geleden ook niet. $\mathrm{Nu}$ blijken wonderbare genezingen onverklaarde genezingen en geen wonderen, dus in de tijd van Jezus gebeurden er ook geen wonderen - om maar een problematische zin op te schrijven die het probleem goed laat zien. Het principe van de analogie rust dus op de veronderstelling dat de structuur van de werkelijkheid nooit verandert en er geen invloeden "van buiten" zijn die soms wel en soms niet meespelen. Dat is het

$4 \quad$ In Wessel Stoker (2000:78). Voor de problematiek van het vaststellen van de feiten over gebeurtenissen en de betekenis van gebeurtenissen en historische ontwikkelingen, zie het brede overzicht van Edwin Koster (2005:75-125), en over bijbelse geschiedenisverhalen tussen feit en fictie, 223331, m.n. 318-327. 
derde principe van de correlatie: alle gebeurtenissen hangen restloos met elkaar samen ${ }^{5}$. Dit methodische uitgangspunt verbiedt historische uitspraken over ingrepen van buiten de samenhangen in de wereld en dus van buitenaf en sluit zo constateringen over het bovennatuurlijke en dus over het handelen van God of geesten uit. In feite betekent dit dat het wereldbeeld van de historicus bepalend is voor wat hij of zij mogelijk en onmogelijk acht. We stuiten hier dus op dezelfde problematiek als in de doordenking van de idee van 'intelligent design' die werd verworpen door mensen die niet in God kunnen geloven én door mensen die zeggen dat de natuurwetenschap zich van dergelijke uitspraken moet onthouden. Naar aanleiding daarvan heb ik gesteld dat de empirische en theoretische natuurkunde zich van spreken over God moet onthouden maar dat zij de verwondering over de natuurlijke ordeningen en de idee van “design” wel kan inbrengen in de filosofie van de natuur, van waaruit een stap naar de wijsgerige godsleer en de theologie noodzakelijk is ${ }^{6}$. Een dergelijke ordening van vakgebieden is ook hier noodzakelijk, want hoe zou historicus ooit op grond van bijbelteksten kunnen bewijzen dat Jezus echt is opgewekt uit de doden? Dat zou in de richting gaan van een godsbewijs op grond van historische documenten... Natuurlijk kan de bijbelwetenschapper uit de bronnen niet bewijzen dat God de profeet Elia heeft geroepen. Intussen kan de bijbelwetenschapper de betekenis van de bijbelse geschriften wel verhelderen en laten zien waarom men ze componeerde zoals men deed, en welk beeld van God, mens en wereld men wil laten oplichten. Als die betekenis voor de huidige lezer oplicht, gaat "wat het betekende" over in "wat het betekent" kunnen we zeggen onder verwijzing naar wat Henk Leene schreef.

Voor de bijbelse geschriften (en heel de theologie) geldt in sterke mate dat objectiviteit en subjectiviteit zijn verweven. Kennis is altijd persoonlijke kennis - dat kan weliswaar van heel de wetenschap worden gezegd (Polanyi 1958), maar het speelt op het ene gebied natuurlijk op een heel andere manier dan op het andere.

5 Ernst Troeltsch (1971:105-127). In de discussie over theologie als wetenschap en de problematiek die in ons hoofdstuk aan de orde is vormen deze criteria van Troeltsch een vast referentiepunt. Zie een kritische bespreking ervan bij Pannenberg (1967:46-54).

$6 \quad$ Zie mijn 2006: hoofdstuk 4; te publiceren in Verbum et Ecclesia als "Veronderstelt de schepping intelligentie?". 
Een uitspraak dat God Israël bevrijdde of dat Jezus de Heilige Geest ontving, veronderstelt uiteraard geloof - de uitspraak dat de bijbelse teksten dat zo vertellen niet. Een andere vraag is of de natuurwetenschapper plaats mag inruimen voor verwondering en zich misschien soms in zijn onderzoek door deze verwondering mag laten inspireren - misschien gaat een geleerde daardoor wel anders "kijken" en vindt hij andere feiten? Men zegt vaak dat de bijbelwetenschap moet uitgaan van "methodisch atheïsme" of agnosticisme en dat eigen geloof geen rol mag spelen. Het probleem daarbij is dat deze houding een waas van ongeloof over bijbelonderzoek legt. In publicaties wordt dan altijd omzichtig afstand genomen van geloof zodat altijd duidelijk is dat de onderzoeker het voor verantwoordelijkheid van de schrijvers laat, met frasen als "mensen geloofden dat..." en "de bijbelschrijver beweert dat...” Daardoor kan een bepaalde retoriek ontstaan die lijkt te suggereren dat de bijbelschrijvers maar wat beweren en dat het bijbelse beeld van de werkelijkheid geheel en al een construct van het oude jodendom en de vroege kerk is. Dit is precies het punt waar Nico Bakker een oplossing forceert waarbij historisch onderzoek geheel wordt vrijgegeven en daarnaast bijbeluitleg bestaat die strikt aan geloof is gebonden. Maar zo neemt men de aard van de bijbel als getuigenis wel serieus maar verliest men m.i. teveel de band tussen verhaal en wat er gebeurd is - ook als dat zich in verten bevindt die men niet meer precies in kaart kan brengen. Als de grote daden van God alleen verhaal zijn, zijn het geen daden meer. Om die reden willen Tjitze Baarda en anderen de band tussen tekst en gebeurtenis niet loslaten. Bij de opstanding van Christus hebben we alleen de berichten van de evangelisten en van Paulus. Hun getuigenis berust niet op een exacte kennis van hoe Jezus is opgewekt uit de doden maar op zijn verschijningen, die maakten dat de eerste discipelen met zekerheid vaststelden dat Hij het zelf was. "[H]et 'oermoment' zelf (blijft) voor ons verborgen, zodat daarover ook door ons achteraf geen uitspraak kan worden gedaan”, schrijft Baarda (1991:306). Uiteraard kunnen we nooit nauwkeurig weten wat er is gebeurd, omdat Jezus' opstanding de ons bekende kaders te buiten gaat. Precies dat is de reden waarom de wetenschap van de opstanding en verschijningen ook niet kan bewijzen dat het niet is gebeurd. Uitspraken over God zijn geen uitspraken waarmee ieder mens het eens zal zijn en in die zin zijn ze niet algemeen-rationeel (Koster 2005:452-462). Als de historicus precies kon vaststellen dat Jezus uit de doden is opgewekt en dat ook kon verklaren, dan zou hij 
een godsbewijs hebben geleverd en de manier waarop God handelt, hebben verklaard - dat is teveel gevraagd. Wat Baarda in zijn artikelen over de opstanding daarentegen wel doet, is laten zien hoe Matteüs, Marcus, Lucas, Johannes en Paulus elk vanuit een eigen perspectief en in een eigen deel van de vroege kerk het verhaal vertellen en de betekenis ervan in wijdere verbanden uitleggen en tegen verschillende vormen van onbegrip en ongeloof afschermen. In zulke uiteenzetting gaat het ook om "wat de auteur zegt”, maar zonder de seculiere afstandelijkheid die dat waas van ongeloof suggereert. Wat christenen in de bijbel hebben, zijn getuigenissen en toelichtingen van wat mensen in hun onderlinge relaties en in relatie tot God overkwam en in allerlei gedeelten van de bijbel ook doordenkingen daarvan — soms heel kritische gedachten en worstelingen met het geloof. De verhalen over wat gebeurd is, bedoelen vooral inzicht over te brengen, bekendheid met en vertrouwen op God. Zoals de veel geciteerde motivering in het evangelie naar Johannes het zegt: "deze zijn opgeschreven opdat $u$ gelooft dat Jezus de Messias is, de Zoon van God, en opdat u door te geloven leeft door zijn naam" (20:21). De verhalen over oude geschiedenissen gaan vermoedelijk terug op oude overleveringen die tot een samenhangend verhaal zijn gecomponeerd. Er zijn fragmenten die de samenhang doorbreken of om andere redenen laten zien dat de schrijvers oude overleveringen hebben opgenomen omdat ze die met eerbied wilden bewaren. Er zijn ongerijmdheden die opzettelijk zijn ingebracht om verbanden te leggen en lezers beter inzicht te geven in waar het om gaat. Is de bijbel dan betrouwbaar of niet? De kerkelijke belijdenis zegt niet dat de bijbel onfeilbaar is als verslag over wat er allemaal gebeurd is - met de oude Latijnse en in sommige kringen gangbare Engelse term inerrantia (inerrancy: geen enkele vergissing). De kerk zegt ook niet dat elke vertelling voorbeeldig is. Integendeel, de bijbel toont vaak ook menselijke zwakheden, niet alleen hoe het kan maar ook hoe het niet moet. In de oude geschiedenissen worden gruwelijkheden verteld die in de latere delen van de bijbel niet meer zouden passen. Gezien vanuit Jezus' optreden als broeder van de "minste mensen" en zijn vermaning om vijanden lief te hebben, moeten we sommige bijbelse vertellingen onder kritiek stellen, en niet alleen omdat ze ons onsympathiek maar omdat ze vanuit de kern van het Evangelie gezien verkeerd zijn. De bijbel vertelt niet alleen geschiedenis maar is ook zelf een ontwikkeling waarin het beeld van God steeds helderder wordt. Juist daar ligt de betrouwbaarheid van de bijbel. De 
Nederlandse Geloofsbelijdenis zegt, zoals al aangehaald, dat in de bijbel genoegzaam geleerd wordt wat de mens nodig heeft om zalig te worden. Het zijn composities, maar serieuze composities. Ze zijn vanuit geloofsperspectief geschreven; geloof beschrijven en ervan getuigen zonder geloofsperspectief is nu eenmaal onmogelijk. Dat het geloofsperspectief niet neutraal kan worden bewezen, komt niet door een gebrek in de aard van geloofskennis, want het vloeit voort uit de beperktheid van neutrale rationaliteit met haar eis van doorzichtigheid en algemeen-geldigheid. Mensen hebben laatste vragen en komen in de knoop door tegengestelde verplichtingen; mensen verwonderen zich over de orde in de natuur, het wonder van het leven en de graankorrel die sterft om nieuw leven voort te brengen. Mensen verheugen zich over vriendschap en rouwen over verlies. In die diepte van menselijke ervaring stopt de nauwkeurige maar kille rationaliteit en begint de poëzie, het verhaal en het getuigenis over hoe het leven echt is, hoe het niet is en hoe het zou moeten zijn. Bijbelverhalen, psalmen en geloofsdoordenkingen liggen op dat gebied. Deze onderwerpen kan men alleen begrijpen in een "meegaande beweging", als men zich opent en ook zelf laat aanspreken door de teksten.

Ondermijnt de bijbelkritiek het christelijk geloof? Het antwoord is simpel: als men de bijbel leest zoals die zelf is en niet met andere maatstaven wil beoordelen, dan is de bijbel betrouwbaar. De traditie die vanuit deze geschriften is ontstaan is echter niet simpel. Hoe men de bijbel leest en toepast in verschillende tijden, levensfasen en situaties is even bont als het leven zelf. Binnen de levende traditie zal er altijd discussie zijn over de voortzetting van die traditie en mensen zullen altijd weer meningsverschillen hebben en in verschillende delen van de wereld andere uitdrukkingen gebruiken om hun geloof onder woorden te brengen. Dat hoort bij tradities ${ }^{7}$.

\section{Literatuurverwijzingen}

Aalders, G Ch 1952. Oud-testamentische canoniek. Kampen: Kok.

Almond, G A R, Scott, A and Emmanuel S 2003. Strong Religion. The Rise of Fundamentalisms around the World. Chicago: University of Chicago Press.

$7 \quad$ Vgl. de klassieke beschrijving van Smith (1964) over de uitwaaiering van tradities. 
Baarda, T 1966. Het gezag van de Heilige Schrift. Gereformeerd Theologisch Tijdschrift 66, 82-106.

-, 1967a. De betrouwbaarheid van de evangeliën. Kampen: Kok.

-, 1967b. De aard van het gezag der Schrift. Opdracht en dienst 42(1), 20-23.

-, 1968. De zon, die stil stond.... Regelrecht 5(2), 33-49.

-, 1969. Over exegese gesproken, Vox Theologica 39, 146-154.

-, 1991. T Baarda, 'Als Christus niet is opgewekt...' Het Nieuwe Testament in het 'Geding', in Kerk en Theologie 1991.

Bakker, N T 1997. Hoe historisch is het woord?, in Kerk en Theologie 48, 276286.

Barth, K 1932/1938. Kirchliche Dogmatik. Band I/1, München; Band I/2, Zürich.

Bavinck, H 1967. Gereformeerde Dogmatiek. Deel I. Kampen: Kok. $5^{\mathrm{e}}$ ed.

Berendsen, D 2001. Waarom geloven mensen? Kampen: Kok.

Deurloo, K 1981. Waar gebeurd. Over het onhistorische karakter van bijbelse verhalen. Baarn: Ten Have.

Gadamer, H-G 1965. Wahrheit und Methode. Tübingen: Mohr.

Green, G 1989. Imagining God: Theology and the Religious Imagination. San Francisco: Harper.

Jonkers, P 2004. The Tension between Representation and Concept as a Challenge for Philosophy of Religion, in Marcel Sarot and Wessel Stoker (eds.). Religion and the Good Life. Assen: Van Gorcum.

Koster, E 2005.In betovering gevangen? Over verhaal en rationaliteit, religie en irrationaliteit. Budel: Damon.

Kraus, H-J 1969. Geschichte der historisch-kritischen Erforschung des Alten Testaments. Neukirchen: Neukirchener Verlag. $2^{\text {de }}$ herz. druk.

Leene, H 1999. Wereldbeeld en geschiedenisbeeld, in Wessel Stoker en Henk C van der Sar (red.). Theologie op de drempel van 2000. Kampen: Kok.

Nammalvar 1993. Hyms for the drowning. Poems for Vishnur. Transl. A.K. Ramamujan. New Delhi: Penguin Books.

Pannenberg, W 1967. Grundfragen systematischer Theologie I. Göttingen: Vandenhoeck \& Ruprecht.

Polanyi, M 1958. Personal Knowledge. Londen.

Schlichting, W 1971. Biblische Denkform in der Dogmatik. Zürich.

Smith, W C 1964. The Meaning and End of Religion. New York: Mentor Books.

Spinoza, B 1997. Theologisch-politiek traktaat, vert., ingel. en van verklarende aant. voorz. door F. Akkerman, Amsterdam: Wereldbibliotheek.

Stoker, W, en Vroom, H 2000. Verhulde waarheid, Over het begrijpen van religieuze teksten. Zoetermeer: Meinema. 
Troeltsch, E 1898 Über historische und dogmatische Methode in der Theologie, in Gerhard Sauter (Hg.). Theologie als Wissenschaft. München 1971, 105127.

Van den Brom, L J 1997. Openbaring in, aan of met de geschiedenis, in Kerk en Theologie 48, 321-336.

Van der Kooi, C 1997. De opwekking van Jezus en onze geschiedenis, in Kerk en Theologie 48, 300-309.

Van der Woude, A S 1997. Geschiede openbaring, in Kerk en Theologie 48, 287-290.

Van Riessen, R D N 2004. Beyond Representation and Concept: The Language of Testimony, in Marcel Sarot and Wessel Stoker (eds.). Religion and the Good Life. Assen: van Gorcum.

Vroom, H M 1978. De Schrift alleen? Kampen: Kok.

-, 1988. Religies en de waarheid. Kampen: Kok [1989. Religions and the Truth. Grand Rapids: Eerdmans].

-, 2003. Een waaier van visies. Godsdienstfilosofie en pluralisme. Kampen: Agora (2006. A Spectrum of World Views. An introduction in the philosophy of religion in a pluralist perspective. Amsterdam - New York: Rodopi).

-, 2006. Plaatsbepaling. Zoetermeer: Meinema.

-, 2007. Veronderstelt de schepping intelligentie? Te publiceren in Verbum et Ecclesia. Zie 2006: hoofdstuk 4. 